\title{
Identification of human T-cell lymphotropic virus infection in a semi-isolated Afro-Brazilian quilombo located in the Marajó Island (Pará, Brazil)
}

\author{
ACR Vallinoto/ ${ }^{+}$, GS Pontes, NA Muto, IGL Lopes, LFA Machado, VN Azevedo, \\ FAPL Carvalhaes*, SEB Santos*, JF Guerreiro*, MO G Ishak, R Ishak
}

Laboratório de Virologia *Laboratório de Genética Humana e Médica, Departamento de Patologia, Centro de Ciências Biológicas, Universidade Federal do Pará, Av. Augusto Corrêa 1, 66075-900 Belém, PA, Brasil

Antibodies to human T-cell lymphotropic virus-1 and 2 (HTLV-1 and 2) were tested in 259 inhabitants (98 males and 161 females) of four villages of the Marajó Island (Pará, Brazil) using enzyme immunoassays (ELISA and Western blot). Types and subtypes of HTLV were determined by nested polymerase chain reaction (PCR) targeting the $p X$, env and $5^{\prime}$ LTR regions. HTLV-1 infection was detected in Santana do Arari (2.06\%) and Ponta de Pedras (1\%). HTLV-2 was detected only in Santana do Arari (1.06\%). Sequencing of the 5 'LTR region of HTLV-1 and the phylogenetic analysis identified the virus as a member of the Cosmopolitan Group, subgroup Transcontinental. Santana do Arari is an Afro-Brazilian community and the current results represent the first report of HTLV-1 infection in a mocambo located in the Brazilian Amazon region.

Key words: human T-cell lymphotropic virus - Afro-Brazilian communities - Marajó Island - Brazil

Human T-cell lymphotropic virus 1 and 2 (HTLV-1 and HTLV-2) are closely related members of a group of mammalian retroviruses which have similar biological properties (Hall et al. 1992). HTLV-1 is endemic worldwide and HTLV-2 infection has been shown to be endemic in native American Indian populations (Hall et al. 1992, Ishak et al. 1995). In Brazil, particularly in the Amazon region, HTLV1 and HTLV-2 infections have been found among urban and rural populations with relevant endemicity (Ishak et al. 1995, 2003, Vallinoto et al. 1998). The molecular epidemiology has been well established concernig HTLV-2 infection and it has shown the occurrence of a new molecular subtype named HTLV-2c (Ishak et al. 1995). However, the molecular analysis of HTLV-1 isolates within Amazonian populations has not been established. The present study describes the presence of HTLV-1 and HTLV-2 in an Amazonian island within two epidemiological partially closed human communities with distinct ethnic background which provides further information for the understanding of the origin and dissemination of the virus in the Amazon region of Brazil.

Two hundred and fifty nine blood samples were collected (98 men and 161 women, ages between 3 to 80 ) from individuals residing in four communities of the Marajó Island, state of Pará, Brazil (Santana do Arari n $=97$, Crairu $n=13$, Tartarugueiro $n=49$, and Ponta de Pedras $n=100$ ). The peripheral blood mononuclear cells (PBMC) and serum samples were obtained and stored at $-20^{\circ} \mathrm{C}$ before use. Santana do Arari and Tartarugueiro are two semiisolated Afro-Brazilian populations, originated from the

Financial support: CNPq, Universidade Federal do Pará +Corresponding author: vallinoto@ufpa.br

Received 24 August 2005

Accepted 14 December 2005 slave escapees during the 17th and 18th centuries.

Serum samples were tested for the presence of antibodies to HTLV-1 and 2 using an enzyme-linked immunosorbent assay (Ortho Diagnostic System Inc., US); positive samples were confirmed by Western blot (HTLV Blot 2.4 GeneLab Diagnostics Ltd, Singapore).

DNA extraction was performed on PBMC from seropositive samples. It was not possible to obtain PBMC from the samples of Ponta de Pedras village. The molecular characterization of HTLV-1 and HTLV-2 infection was performed by nested PCR and RFLP typing of the pX, env and 52 LTR segments using sets of primers, as previously described (Hall et al. 1992, Tuke et al. 1992, Laurentino et al. 2005). Amplified fragments of 52 LTR were purified and sequenced according to a protocol previously reported (Laurentino et al. 2005). The reaction products were loaded on the ABI Prism 377 DNA Sequencer (Perkin-Elmer Cetus).

The sequence alignment of $489 \mathrm{bp}$ from 5' LTR was performed using the BioEdit software (Hall 1999). The phylogenetic relationships among the sequence described in the present study (SNT43, DQ070891 and STN92, DQ070892) and those available in the Genbank were analyzed using the Phylogenetic Inference Package - PHYLIP 3.5v (Felsenstein 1993). A phylogenetic tree was infered by the Neighbour-Joining (NJ) method, using the HKY substitution model. The statistical reliability of NJ tree was evaluated using 1000 boostrap. The tree was drawn with the TreeView 1.4 program (Page 2001).

Serorreactivity to HTLV-1 was detected in two subjects (a man and a woman over 60 years of age) residing in Santana do Arari (2.06\%) and in one woman (age unknown) residing in Ponta de Pedras (1\%). A woman (over 50 years of age) from Santana do Arari presented serorreactivity to HTLV-2 (Table).

Enzymatic digestion with TaqI of the product of $\mathrm{pX}$ region confirmed the infections by HTLV-1 and HTLV-2 
from Santana do Arari, but due to the absence of a DNA sample from the subject from Ponta de Pedras, the molecular confirmation of infection and characterization of the virus were not performed. The restriction analysis with XhoI of the env product from the HTLV-2, showed the presence of two bands which is compatible with molecular subtypes $2 \mathrm{a}$ and $2 \mathrm{c}$. The DNA aliquot was not sufficient to follow through with the molecular characterization, which is necessary to distinguish HTLV-2a from HTLV-2c molecular subtype. Confirmation of HTLV-1 infections was performed by the amplification of a $770 \mathrm{bp}$ sequence of the 5'LTR region. The phylogenetic analysis of the two isolates from Santana do Arari, showed that both samples were members of the Cosmopolitan group, subgroup Transcontinental, supported by bootstrap values of $72 \%$ (Figure).

The present study describes the presence of HTLV-1 and HTLV-2 infections in the Marajó Island (state of Pará, Brazil), an area not previously included in the geographic distribution of HTLV-2. The detection of HTLV-1, Cosmopolitan Group, Transcontinental subgroup is in agreement with other studies that indicate its presence in the rural area of the state of Pará (Vallinoto et al. 2004, Laurentino et al. 2005)

TABLE

Seroprevalence of anti-human T-cell lymphotropic virus 1 and 2 (HTLV-1 and HTLV-2) in four villages of the Marajó Island, state of Pará

\begin{tabular}{lcccc}
\hline & & & \multicolumn{2}{c}{ Western blot } \\
\cline { 3 - 5 } Populations & $\mathrm{N}$ & ELlSA & HTLV-1 (\%) & HTLV-2 (\%) \\
\hline Santana do Arari & 97 & 03 & - & $01(1.03)$ \\
Tartarugueiro & 49 & 00 & - & - \\
Crairú & 13 & 00 & $01(1.0)$ & - \\
Ponta de Pedras & 100 & 01 & $03(1.15)$ & - \\
\hline Total & 259 & 04 & $01(0.38)$ \\
\hline
\end{tabular}

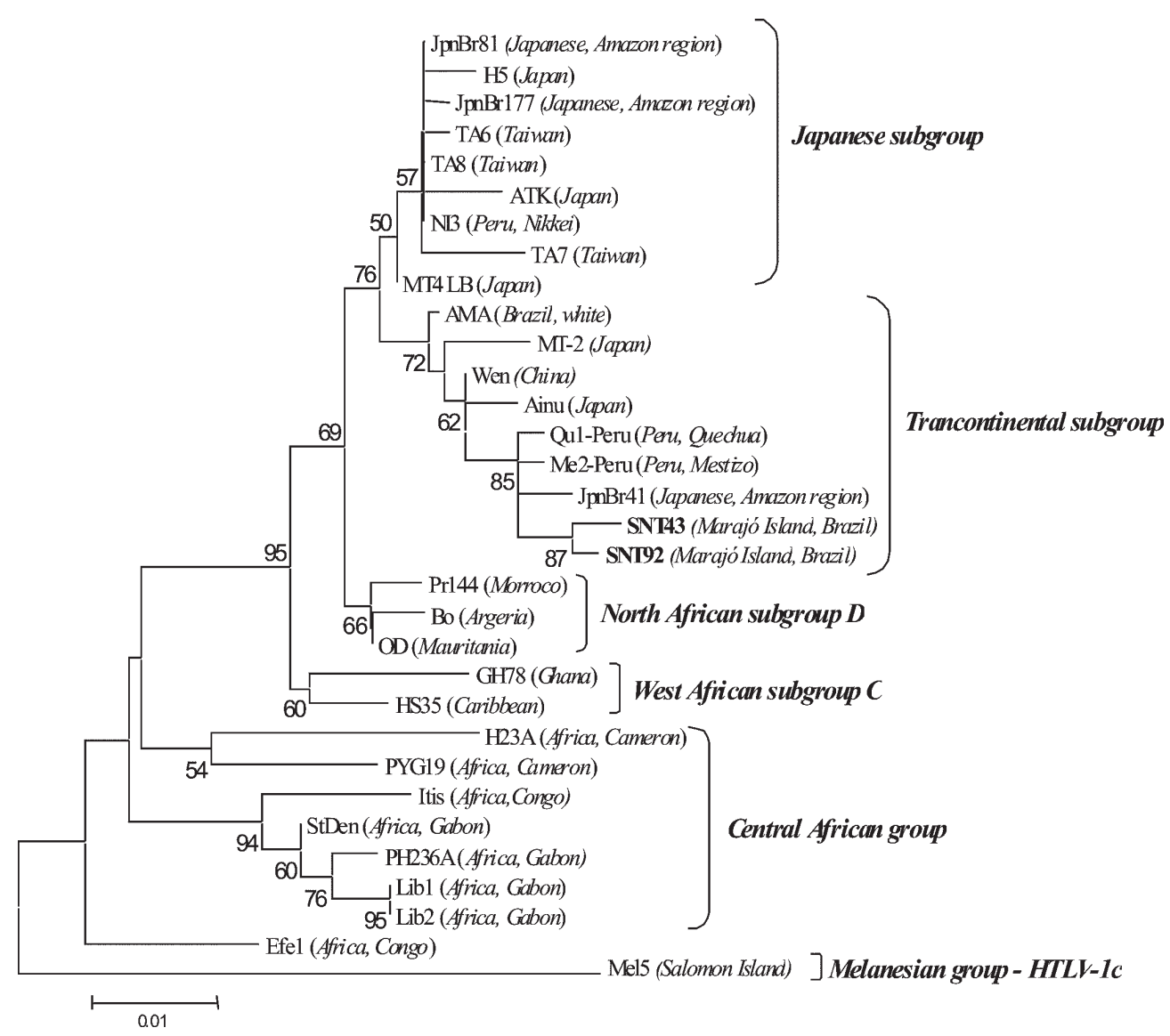

Rooted phylogenetic tree, showing the evolutionary relationship of human T-cell lymphotropic virus 1 strains described thus far including newly sequenced isolates from the present study (SNT43 and SNT92). The tree was constructed by the Neighbour-Joining method after alignment of 489 nucleotides of the 5'LTR region. The Mel5 isolate was used as outgroup. The statistical support was applied using 1000 bootstrap replicates. Cosmopolitan group: Transcontinental (subgroup A), Japanese (subgroup B), West African (subgroup C), North African subgroups (subgroup D). Geographical origin and ethnic origin are described in italics between parenthesis. 
The origin of HTLV-1, Cosmopolitan Group, Transcontinental subgroup, in Latin America is still controversial (Yamashita et al. 1998, Van Dooren et al. 1998). The presence of HTLV-1 and HTLV-2 in the communities studied herein could be attributed to recent contact with infected individuals from the neighboring urban populations.

The Marajó Island was inhabited, during the colonization process, by the European, the African slaves, and the Tupinambá Indians (Miranda-Neto 1976). Santana do Arari is a quilombo originated by African slave descendents, and it is reasonable to suggest a recent entrance of HTLV-1 in the Marajó Island by the African slave trade. Mitochondrial DNA polymorphism analysis has revealed an Indian contribution about $40 \%$ in Santana do Arari (Carvalho et al. 2002) that could explain the occurrence of HTLV-2 in the present community.

Regarding our previous study that did not identified HTLV-1 infection in other Amazonian populations composed by descendents of African slaves (Ishak et al. 2003), the current results represent the first report of HTLV-1 infection in a mocambo located in the Brazilian Amazon region. Furthermore, the presence of HTLV-1 in this geographical area is of paramount importance because of the previous description of a cluster of cases of TSP/HAM in two individuals residing in Cachoeira do Arari county, Marajó Island (Ishak et al. 2002). It is necessary to emphasize the need for a close surveillance and to proceed a further active search for cases of neurological diseases associated to HTLV-1, in this particular geographical area of the country, considering the total of 294 semi-isolated Afro-Brazilian communities recently described in the state of Pará (Eltermann 2005).

\section{ACKNOWLEDGMENTS}

To all the subjects involved in the present study, and to Vilson C Monteiro and Edson S Abrahim Filho for assistance with blood sample collection.

\section{REFERENCES}

Carvalho BM, Elleres EPC, Ribeiro-dos-Santos AKC 2002. Polimorfismo do mtDNA em duas populações afrobrasileiras da Amazônia: Pontal e Marajó. $48^{\circ}$ Congresso Nacional de Genética, Águas de Lindóia, SP.

Eltermann R 2005. Pará é o $3^{\circ}$ do Brasil em área quilombola. O Liberal, edição ano LIX, Caderno Atualidades, no. 31,024 (http://www.oliberal.com.br/) em 08/05/2005.

Felsenstein J 1993. PHYLIP - Phylogeny Inference Package. Version 3.5c. University of Washington, Seattle, US.

Hall TA 1999. BioEdit: a user-friendly biological sequence alignment editor and analysis program for Windows 95/98/ NT. Nucl Acids Symp Ser 41: 95-98.
Hall WW, Takahashi H, Liu C, Kaplan MH, Sheewind O, Ijichi S, Nagashima K, Gallo RC 1992. Multiple isolates and characteristics of human T-cell leukemia virus type II. J Virol 66: 2456-2463.

Ishak R, Cavalcante F, Vallinoto ACR, Azevedo VN, Ishak MOG 2002. HTLV-I associated myelopathy in the Northern region of Brazil (Belem-Para): serological and clinical features of three cases. Rev Soc Bras Med Trop 35: 243-246

Ishak R, Harrington Jr W, Azevedo VN, Eiraku N, Ishak MOG, Guerreiro JF, Santos SEB, Kubo T, Monken C, Alexander S, Hall WW 1995. Identification of human T-cell lymphotropic virus type IIa infection in the Kayapo, an Indigenous population of Brazil. AIDS Res Hum Retrovirol 11: 813-821.

Ishak R, Vallinoto ACR, Azevedo VN, Ishak MOG 2003. The epidemiological aspects of retrovirus (HTLV) infections among Indian populations of the Amazon region of Brazil. Cad Saúde Pública 19: 109-118.

Laurentino RV, Lopes IG, Azevedo VN, Machado LFA, Moreira MRC, Lobato L, Ishak MOG, Ishak R, Vallinoto ACR 2005. Molecular characterization of human T-cell lymphotropic virus coinfecting human immunodeficiency virus 1 infected patients in the Amazon region of Brazil. Mem Inst Oswaldo Cruz 100: 371-376.

Miranda-Neto MJ 1976. Marajó: Desafio da Amazônia, Aspectos da Reação a Modelos Exógenos de Desenvolvimento, Record, Rio de Janeiro, 180 pp.

Page RD 2001. TreeView 1.4 software, University of Glasgow, UK.

Tuke PW, Luton P, Garson JA 1992. Differential diagnosis of HTLV-I and HTLV-II infections by restriction enzyme analysis of nested PCR products. J Virol Method 40: 163-174.

Vallinoto ACR, Azevedo VN, Santos DEM, Carniceiro S, Mesquita FCL, Hall WW, Ishak MOG, Ishak R 1998. Serological evidence of HTLV-I and HTLV-II coinfections in HIV-1 positive patients in Belém, state of Pará, Brazil. Mem Inst Oswaldo Cruz 93: 407-409.

Vallinoto ACR, Muto NA, Pontes GS, Machado LFA, Azevedo VN, Santos SEB, Santos ÂKCR, Ishak MOG, Ishak R 2004. Serological and molecular evidence of HTLV-I infection among Japanese immigrants living in the Amazon region of Brazil. Jpn J Infec Dis 57: 156-159.

Van Dooren S, Gutozo E, Salemi M, Watts D, Audenaert E, Duwe S, Ellerbrok H, Grassmann R, Hagelberg E, Desmyter J, Vandamme A-M 1998. Evidence for a post-Columbian introduction of human T-cell lymphotropic virus in Latin America. J Virol 79: 2695-2708.

Yamashita M, Picchio G, Veronesi R, Ohkura S, Bare P, Hayami M 1998. HTLV-Is in Argentina are phylogenetically similar to those of other South American Countries, but different from HTLV-I in Africa. J Med Virol 55: 152-160. 